The Bangladesh Veterinarian (2009) 26(2) : $74-79$

\title{
Impact of urea-based diets on production of Red Chittagong Cattle
}

\author{
M. A. Habib*, M. S. Hossain and A. K. F. H. Bhuiyan ${ }^{1}$ \\ Department of Animal Breeding and Genetics, Faculty of Animal Husbandry, Bangladesh \\ Agricultural University, Mymensingh-2202, Bangladesh
}

\begin{abstract}
The production traits of Red Chittagong Cattle (RCC) were studied using two diets: A [Urea-molasses-rice straw (UMRS), Green Grass and Concentrate] and B [Rice straw, Green Grass and Concentrate]. In cows fed diets A and B, birth weights of calves were 15.2 and $14.1 \mathrm{~kg}(\mathrm{P}<0.05)$, daily milk yield 2.0 and $2.0 \mathrm{~kg}(\mathrm{P}>0.05)$, lactation length 254.8 and 247.1 days $(P>0.05)$, age at first oestrus 28.4 and 25.6 months $(P<0.05)$, number of services per pregnancy 1.6 and $2.5(\mathrm{P}<0.05)$, onset of postpartum oestrus 141.3 and 109.3 days $(\mathrm{P}<0.05)$, calving interval 14.2 and 13.3 months $(\mathrm{P}<0.05)$, semen volume per ejaculation 3.0 and $3.7 \mathrm{ml}(\mathrm{P}<0.05)$, mass activity of sperm 58.6 and $68.4 \%(\mathrm{P}<0.01)$ and sperm concentration 709.1 and 1289.0 million/ml ( $\mathrm{P}<0.01)$, respectively. (Bangl. vet. 2009. Vol. 26, No. 2, 74-79)
\end{abstract}

\section{Introduction}

Cattle and buffaloes in Bangladesh mainly subsist on a straw-based diet with limited green fodder and little or no concentrate. Out of total dry matter (DM), 70\% constitutes dry roughage, $87 \%$ of which is rice straw (Tareque, 1991). Rice straw is very low in digestibility and highly deficient in protein and micronutrients (Preston and Leng, 1987; Akbar, 1992). However, the animal productivity can be improved by efficient utilization of straw (Preston, 1981). Nutritive value of straw can be improved by physical, chemical and biological means and by supplementation with nitrogen and energy. Urea is a form of Non-Protein Nitrogen (NPN) that can be fed to cattle with caution, incorporated into basal diets. Urea is quickly converted to ammonia in the rumen, which is utilized by the rumen microbes along with readily available energy to produce protein. If energy sources are limited in the rumen or if too much urea is consumed, large amounts of urea can enter the circulatory system. When high amounts enter the bloodstream, the liver fails to detoxify it, as a result cattle may suffer from ammonia toxicity causing death. The digestibility and palatability of rice straw can be increased by addition of urea and molasses forming urea-molassesstraw (UMS). Studies with dairy buffaloes indicated that processing of rice straw with urea and molasses is the best and cheapest option for the small farmers of Bangladesh to boost milk production (Uddin, 2001). Ghosh et al. (1993) reported that growth rate of indigenous (Desi) young cattle increased from 100-200g/day to 300$400 \mathrm{~g} /$ day. Information on nutrition and feeding of RCC is scanty. A study was

\footnotetext{
*Correspondence: E-mail:- ahsan.rony@yahoo.com
} 
carried out to find the impact of feeding straw treated with urea and molasses on some productive traits in RCC.

\section{Materials and Methods}

Source of animals and data

The data on productive and reproductive performance of RCC and their progenies were extracted from the records at the Bangladesh Agricultural University (BAU) Dairy Farm and Artificial Insemination (AI) Center, Mymensingh from 2005 to 2008.

Feeding and management practices in RCC nucleus herd

The nucleus herd of RCC was stall-fed throughout the year. Rice straw, the main feed, was provided in two forms: straw alone, and straw treated with urea and molasses, ad libitum. Maize and German grass (Echinocloa crusgalli) were fed to the animals at 10, 5, 3 and $2 \mathrm{~kg} /$ head/day for stud bulls, lactating cows, pregnant cows and heifers, respectively. Concentrate was provided to the animals in the morning at $2.0,0.5,0.4$ and $0.25 \mathrm{~kg} / \mathrm{head} /$ day for stud bulls, lactating cows, pregnant cows and heifers, respectively (Table 3). Clean drinking water was supplied ad libitum. Vaccination against Anthrax was done annually. Foot and Mouth Disease vaccine and anthelmintics were given every six months.

\section{Feeding trials}

Two diets were fed and shown in Table 1.

Table 1. Feeding trials for the RCC nucleus herd

\begin{tabular}{cl}
\hline Treatments & \multicolumn{1}{c}{ Diets } \\
\hline $\mathrm{A}$ & Urea-molasses- rice straw (UMRS) + Green grass + Concentrate \\
$\mathrm{B}$ & Rice straw + Green grass + Concentrate \\
\hline
\end{tabular}

Compositions of feed ingredients are shown in Tables 2 and 3.

Table 2. Composition of UMRS

\begin{tabular}{lc}
\multicolumn{1}{c|}{ Components } & Amount $(\mathrm{kg})$ \\
\hline Chopped straw & 100 \\
Molasses & 20 \\
Urea & 03 \\
Water & 100 \\
\hline
\end{tabular}

Birth weight, lactation length and milk yield were recorded as described by Khan et al. (2001) and semen volume, sperm motility and sperm concentrations 
following procedures of Alam et al. (2005). Age at first oestrus, services per pregnancy, onset of postpartum oestrus and calving interval were recorded following the procedures of Majid et al. (1995).

Table 3. Composition of concentrate mixture

\begin{tabular}{l|c}
\hline \multicolumn{1}{c|}{ Ingredients } & Amount (\%) \\
\hline Wheat bran & 30 \\
Rice polish & 15 \\
Mustard oil cake & 15 \\
Corn (crushed), & 30 \\
Di-calcium phosphate (DCP) & 05 \\
Common salt & 05 \\
Vitamin - Mineral- premix & 0.01 \\
Statistical analysis &
\end{tabular}

The data were entered into Microsoft Excel worksheet, organized and processed for further analysis. Means and standard errors were calculated using Statistical Packages for Social Science (SPSS-10.0) computer program. To find out the effect of feeding trials, least significant difference (LSD) was tested with analysis of variance (ANOVA) using the procedure by SPSS-10.0.

\section{Results and Discussion}

Production traits of RCC on the two different diets are shown in Table 4a.

Table 4a. Mean \pm SE of production traits of RCC fed two diets

\begin{tabular}{l|c|c|c}
\hline \multirow{2}{*}{ Traits } & \multicolumn{2}{c|}{ Feeding regime } & \multirow{2}{*}{$\begin{array}{c}\text { Level of } \\
\text { significance }\end{array}$} \\
\cline { 2 - 3 } & $\mathrm{A}$ & $\mathrm{B}$ & $*$ \\
\hline Birth weight $(\mathrm{kg})$ & $15.2 \pm 0.3$ & $14.1 \pm 0.5$ & $\mathrm{NS}$ \\
Milk yield (kg/day) & $2.0 \pm 0.03$ & $2.0 \pm 0.1$ & $\mathrm{NS}$ \\
Lactation length (days) & $254.8 \pm 10.9$ & $247.1 \pm 13.5$ & $*$ \\
Semen volume (ml/ejaculation) & $3.0 \pm 0.2$ & $3.7 \pm 0.2$ & $* *$ \\
Motility of sperm (\%) & $58.6 \pm 0.8$ & $68.4 \pm 1.2$ & $* *$ \\
Sperm concentration (million/ml) & $709.1 \pm 32.9$ & $1289.0 \pm 30.9$ &
\end{tabular}

Cows fed diet A produced calves with higher birth weight $(\mathrm{P}<0.05)$ than the cows fed diet B (Table 4a). This might be due to the fact that urea-treated diet improved the body condition score (BSC) in pregnant cows. The results are not in agreement with Bond and Oltjen (1973) who found lower birth weights of calves 
whose dams' diets were supplemented with urea than those whose dams were fed urea and soybean, or soybean concentrates, but the difference was not significant $(\mathrm{P}>0.05)$.

The milk yields are given in Table 4a: the differences were not significantly different $(\mathrm{P}>0.05)$. The result is consistent with Bond and Oltjen (1973) who found similar results $(\mathrm{P}>0.05)$ among three dietary treatments (urea, urea + soybean meal, soybean). Mazed (1997); Miah et al. (2000); Chowdhury (2004); Alam et al. (2006) and Ferdous et al. (2007) in indigenous and crossbred cows found better $(\mathrm{P}<0.05)$ milk yield in cows fed UMB than controls (without urea). Vu et al. (1999) found better $(\mathrm{P}<0.05)$ daily milk yield in crossbred Holstein-Friesian cattle fed urea-treated rice straw than in those without urea. These results are in contrast with the results of the present study, probably due to different genotype, age, management practices and duration of treatment.

The average lactation lengths (Table 4a) were not significantly different $(\mathrm{P}>0.05)$.

Table 4a shows that semen volume, sperm motility and sperm concentration were significantly $(\mathrm{P}<0.05)$ better in bulls fed no urea $(\mathrm{B})$ than those fed urea $(\mathrm{A})$. The results indicate that straw treated with urea and molasses is not suitable for breeding bulls. This might be due to detrimental effect of nitrogen. The result is supported by Sherbeiny (2000) who fed formaldehyde-treated concentrate resulting in significantly $(\mathrm{P}<0.05)$ poorer semen quantity and quality in Friesian bulls. However, further study needs to be done for definite conclusion.

The reproductive traits of RCC on the two different diets are shown in Table $4 \mathrm{~b}$. It shows that cows fed no urea (B) matured earlier than cows fed urea (A).

There were fewer services per pregnancy $(\mathrm{P}<0.05)$ in cows fed urea $($ Table $4 \mathrm{~b})$. This result is agreed with the results of Chowdhury (2004) and Ferdous et al. (2007) who found significantly $(\mathrm{P}<0.05)$ fewer services per pregnancy in urea-supplemented cows than without supplementation.

Table $4 \mathrm{~b}$. Mean \pm SE of reproductive traits of RCC fed two different diets

\begin{tabular}{l|c|c|c}
\hline \multirow{2}{*}{ Traits } & \multicolumn{2}{c|}{ Diet } & \multirow{2}{*}{$\begin{array}{c}\text { Level of } \\
\text { significance }\end{array}$} \\
\cline { 2 - 3 } & $\mathrm{A}$ & $\mathrm{B}$ & $*$ \\
\hline Age at first oestrus (months) & $28.4 \pm 1.6$ & $25.60 \pm 2.02$ & $*$ \\
Number of services per pregnancy & $1.6 \pm 0.2$ & $2.5 \pm 1.5$ & $*$ \\
Onset of postpartum oestrus (days) & $141.3 \pm 11.1$ & $109.3 \pm 9.76$ & $*$ \\
Calving interval (months) & $14.2 \pm 0.5$ & $13.3 \pm 0.3$ & $*$ \\
\hline
\end{tabular}

${ }^{*} \mathrm{P}<0.05,{ }^{* *} \mathrm{P}<0.01$

The cows fed urea $(\mathrm{A})$ had significantly $(\mathrm{P}<0.05)$ delayed onset of post partum oestrus (Table $4 \mathrm{~b}$ ). The result is not consistent with other reports (Mazed, 1997; Miah et al., 1999; Chowdhury, 2004; Ferdous et al., 2007) where significantly $(\mathrm{P}<0.05)$ earlier post-partum oestrus occurred in cows fed urea. Vu et al. (1999) found earlier post 
partum oestrus in crossbred Holstein-Friesian cows fed urea-treated straw than in controls $(\mathrm{P}<0.05)$. This result differs from the present study: this might be due to differences of age, genotype, feeding, management, duration of treatment or formulation of urea treatment.

Calving interval depends on genetics of dam, feeding, management, and disease. The cows fed control diet $(\mathrm{B})$ showed shorter calving interval $(\mathrm{P}<0.05)$ than cows fed urea $(\mathrm{A}$; Table $4 \mathrm{~b})$. Significantly $(\mathrm{P}<0.05)$ shorter calving interval in indigenous and crossbred cows were found in cows fed urea than controls (Miah et al., 1999; Mazed,1997; Chowdhury, 2004). Vu et al. (1999) found significantly $(\mathrm{P}<0.05)$ shorter calving interval in crossbred Holstein-Friesian cows fed urea-treated straw than those fed untreated straw. These results are in contrast with the present study. The differences might be due to difference of age, genotype, feeding, management and duration of treatment.

Feeding of urea-treated straw adversely affected the reproductive performance of RCC except the number of services per conception. However, most other studies indicated improved reproductive performance. High protein intake may influence the reproductive system through changes in liver function with the concomitant increase of energy demand by deamination of excess amino acids (Visek, 1984). Excess ammonia reduces intermediary metabolism and increases blood concentrations of urea, glucose, non-esterified fatty acids and insulin. Smith (1986) reported that some nitrogenous end-products might alter the functioning of the hypophyseal-pituitary-ovarian axis, decreasing LH pulse frequency and amplitude. Birth weight of calves might be higher in cows fed urea-treated diet, resulting in good maternal body condition. Milk production was not changed significantly by the urea diet.

It would appear from this study that a urea-treated diet is not suitable for a breeding bull, because it decreased quantity and quality of semen.

\section{References}

Akbar MA 1992: Methods of urea incorporation in straw and their effects on performance of buffalo heifers. Asian-Australasian Journal of Animal Science 5 544-547.

Alam MGS, Azam MSU, Khan, MJ 2006: Supplementation with Urea and Molasses and body weight, milk yield and onset of ovarian cyclicity in cows. Journal of Reproduction and Development 52 529-535.

Alam MGS, Yeasmin S, Bari FY, Mishra B 2005: The effect of duration of preservation on the quality of chilled bull semen. The Bangladesh Veterinarian 22 16-22.

Bond J, Oltjen RR 1973: Growth and reproductive performance of beef females fed high urea-containing diets. Journal of Animal Science 371040-1047.

Chowdhury MAR 2004: Effects of urea molasses block on productive and productive performance of crossbred dairy cattle. PhD Thesis, Department of Dairy Science, Faculty of Animal Husbandry, Bangladesh Agricultural University, Mymensingh, Bangladesh. 
Ferdous Z, Khan MAS, Siddiki MSR, Habib MA 2007: Response to Urea Molasses Block (UMB) feeding of lactating cows reared under village condition of Bangladesh. Journal of Bangladesh Society for Agricultural Science \& Technology 4 161-164.

Ghosh A, Alam MGS, Akbar MA 1993: Effect of urea molasses mineral block supplementation on postpartum ovarian activity in Zebu cows. Animal Reproduction Science 31 61-67.

Khan MS, Islam MN, Hashem MA, Sultana Z 2001: Milk productive performance of indigenous and crossbreds cows of private dairy farm. Bangladesh Journal of Animal Science 30 15-19.

Majid MM, Nahar TN, Talukder AI, Rahman MA 1995: Reproductive performance of purebred, $F_{1}, F_{2}$ and $F_{3}$ cows related at Savar dairy farm. Bangladesh Journal of Livestock Research 2 53-62.

Mazed MA 1997: Effect of urea molasses multinutrient block on the productive and reproductive performance of indigenous zebu cows under the village condition of Bangladesh using RadioImmunoassay techniques. MS Thesis, Department of Dairy Science, Faculty of Animal Husbandry, Bangladesh Agricultural University, Mymensingh, Bangladesh.

Miah AG, Salma U, Khan MAS Islam MN 1999: Effects of urea-molasses multinutrientsblocks on the reproductive performance of indigenous (Zebu) cows. Progressive Agriculture 10 75-78.

Miah AG, Salma U, Khan MAS, Ali ML 2000: Effect of urea-molasses multinutrientsblocks on the productive performance of indigenous cows. Bangladesh Journal of Animal Science 29 135-142.

Preston TR 1981: Supplementation of Paddy straw and other tropical by-products for cattle. Proceeding of a Seminar on "Maximum livestock production from minimum land" held at Bangladesh Agricultural University, Mymensingh, Bangladesh.

Preston TR, Leng RA 1987: Matching Ruminant Production Systems with Available Resources in the Tropics and Subtropics. Penambul Books, Armidale, NSW, Australia.

Sherbeiny MAEGE 2000: Physiological studies on reproduction of farm animals (Effect of feeding protected protein diets on reproductive performance of Friesian Bulls). Animal Production Research Institute (APRI), Biotechnology Division, Egypt, 705 pp. 123.

Smith MF 1986: Recent advances in corpus luteum physiology. Journal of Dairy Science 69 \& 91 1-926.

Tareque AMM 1991: Feeds and Fodder Resources in Bangladesh and Patterns of Utilization, ADS, Second Livestock Project, TA \# 668-BAN, Dhaka, Bangladesh.

Uddin MM 2001: A comparative study on some productive $\mathcal{E}$ reproductive economic traits of different genetic groups of dairy cows in military farm, Savar $\mathcal{E}$ CCBS, Savar, Dhaka. MS Thesis. Department of Dairy Science, Faculty of Animal Husbandry, Bangladesh Agricultural University, Mymensingh, Bangladesh.

Visek WJ 1984: Ammonia: its effects on biological systems, metabolic hormones, and reproduction. Journal of Dairy Science 67 481-498.

Vu DD, Cuong LX, Dung CA, Hai PH 1999: Use of urea-molasses-multinutrient block and urea-treated rice straw for improving dairy cattle productivity in Vietnam. Preventive Veterinary Medicine 38 187-193. 